\title{
Gyorgy Lukàcs (1885-1971): um marxista trágico
}

\section{RESUMO}

A vida de Gyorgy Lukàcs repercute de uma maneira surpreendente em algumas frases de sua Théorie sur le Roman (Teoria sobre o Romance), publicada em 1916. Nessa obra, ele diz: " $(\mathrm{O})$ herói trágico se substitui ao homem vivo de Homero, [...] porque ele recebe dele sua chama que está se apagando e que ele faz brilhar de novo". Intitulado Les civilisations closes, este ensaio explora o mundo da epopéia, aquele de uma unidade metafísica irrespirável para todos.

\section{PALAVRAS CHAVE}

Gyorgy Lukàcs

Marxismo trágico

Teoria sobre o romance

\section{ABSTRACT}

The life of Gyorgy Lukacs on, in an amazing way, in a few sentences of his Théorie sur le Roman (Theory of the Novel), published in 1916. In it he says: "(O) tragic hero replaces the living man of Homer, [...] because he gets it that the flame is fading and he does shine again." Titled "Les civilizations closes, this essay explores the world of epic, that of a metaphysical unity breathable for all.

\section{KEYWORDS}

Gyorgy Lukacs

Tragic marxism

Theory of the novel

\section{Patrick Tacussel}

Diretor do Institut de Recherches Sociologiques \& Anthropologiques e do Centre de Recherches sur I'Imaginaire IRSA-CRI/FR.

patrick.tacussel@univ-montp3.fr
A vida de Gyorgy Lukàcs repercute, de uma maneira surpreendente, em algumas frases de sua Théorie sur le Roman (Teoria sobre o Romance), publicada em 1916. Nessa obra, ele diz: " $(\mathrm{O})$ herói trágico se substitui ao homem vivo de Homero, [...] porque ele recebe dele sua chama que está se apagando e que ele faz brilhar de novo"1. Intitulado Les civilisations closes, o primeiro capítulo deste ensaio explora o mundo da epopéia, aquele de uma unidade metafísica irrespirável para todos. Páginas premonitórias para este intelectual comunista de primeiro plano, do qual Thomas Mann tomará, em 1924, o destino através do personagem de Naphta em La montagne magique (A Montanha Mágica). Os escritos da juventude do filósofo húngaro contribuíram mais para seu reconhecimento internacional e para sua posteridade do que a contrariedade em ocupar um posto no seio da intelligentsia do bloco soviético.

\section{Seus trabalhos se caracterizam, doravante, por uma aversão violenta em relação ao modernismo e às vanguardas 10 expressionismo alemão, 0 surrealismo).}

Publicado em 1911, L'Ame et les Formes (A Alma e as Formas) $)^{2}$ é um estudo marcado pela influência do Círculo Max Weber, de Heidelberg, e do Círculo de Domingo, de Budapeste; o título também sublinha o importante papel de Georg Simmel (1858-1918) na sua formação universitária. A alma transcende as tensões antagonistas da existência. Ela, a alma, ultrapassa tudo o que a afeta do exterior; ou seja, dinamismo profundo da vida, enquanto a consciência padece dos efeitos 
de alienação social em sua totalidade (a mercadoria, o trabalho, a ação militante, a fé, etc.). A alma se eleva para além das preocupações objetivas com as quais o sujeito se defronta na realidade. Ela remete à salvação religiosa e sua concretização profana em certas questões da vida terrestre, em especial políticas.

\section{Os escritos da juventude do filósofo húngaro contribuíram mais para seu reconhecimento internacional e para sua posteridade do que a \\ contrariedade em ocupar um} posto no seio da

\section{intelligentsia do bloco} soviético.

Gyorgy Lukàcs se converteu ao marxismo entre 1917 e 1919, a partir de uma "visão trágica do mundo" baseada na rejeição ética da velha monarquia austrohúngara ao mesmo tempo feudal e burguesa, e o dever de dar a essa revolta a chance de uma praxis concreta, aquela de um engajamento revolucionário. Ligado às doutrinas da nascente III International, ele desenvolve, em 1923, em Histoire et conscience de classe (História e Consciência de Classe) ${ }^{3}$, as teses prontamente indexadas pela ortodoxia bolchevique e pela socialdemocracia. Ele não demora a renegar esta obra magistral cujos exemplares serão, logo, destruídos. Este livro aprofunda o tema da réification (reificação) em Karl Marx. Gyorgy Lukàcs se dedica a mostrar que ela envolve todos os aspectos da submissão alienada à economia capitalista, da mesma forma que corrompe a legitimidade das burocracias modernas fundadas na racionalização formal do Direito, do Estado, das administrações, estendendo-se, igualmente, ao funcionamento e às reivindicações dos partidos e dos sindicatos dos trabalhadores.
Compreende-se, portanto, a reação hostil dos dirigentes do movimento socialista: ao desvendar os mecanismos de dominação das coisas sobre os homens, os proprietários da guerra de classes são confundidos por um teórico egresso do seu meio e que defende a autonomia do proletariado, imperativo indispensável de sua missão histórica. A subjetividade, tema maior desta questão, consagra a consciência de classe do proletariado como única resposta global capaz de subverter o universo infeliz da falsidade. Diversos comentaristas concordam em ver no Être et Temps (Ser e Tempo), de Martin Heidegger (1927), uma refutação da Histoire et conscience de classe.

Escapando ao fascismo, ele se refugia em Moscou a partir de 1933. Retorna a Budapeste em 1944, onde começa uma carreira de professor de História da Arte e de Estética. Sua vasta cultura o conduz a produzir estudos de excepcional qualidade sobre Goethe, Balzac e o realismo francês; Thomas Mann, o jovem Hegel, e, finalmente, uma obra sobre a estética. Todos os seus livros são traduzidos na França desde 1947. Seus trabalhos se caracterizam, doravante, por uma aversão violenta em relação ao modernismo e às vanguardas (o expressionismo alemão, o surrealismo). Implacável crítico da ideologia burguesa, Gyorgy Lukàcs critica igualmente a filosofia de Nietzsche e o existencialismo através dos quais ele observa os sintomas do niilismo contemporâneo, patologia social do liberalismo burguês, doravante privado das promessas progressistas de seu advento. La Destruction de la Raison (A Destruição da Razão), de 1954, expõe, em tom dogmático, a decadência mental da vida de artifício na civilizações capitalista e imperialista.

No começo dos anos 60, Gyorgy Lukàcs encontra na França um público que destaca a originalidade de sua obra na juventude. Lucien Goldmann, Kostas Axelos e Joseph Gabel acabam contribuindo para esse reconhecimento. Este último estabelece uma ligação entre a teoria lukàcsienne da reificação e a esquizofrenia analisada sob o ponto de vista psicopatológico ${ }^{4}$. Guy Debord cita Histoire et conscience de classe, no segundo capítulo, La marchandise comme spectacle (A Mercadoria como Espetáculo), em La Société du spectacle (A Sociedade do Espetáculo), de 1967. G. Lukàcs torna-se o teórico de uma radicalidade que ele abandonou há vários anos. Foi, precisamente, em 1967 que ele havia sido reintegrado - a seu pedido - ao Partido Comunista húngaro, no qual ele tinha sido cassado por ter participado da revolução de 1956 e a sua função de Minis- 
tro da Cultura no primeiro governo de I. Nagy. Esta questão confirma "uma reconciliação extorquida", descrita em um artigo de Theodor W. Adorno, a partir de 1958, como a de uma trajetória perdida em uma odisséia política na qual ele percebia, no oposto aos burocratas de plantão, o "vencimento" inelutável n FAMEcos

\section{REFERÊNCIAS}

ADORNO, Theodor. Une réconciliation extorquée. Der Monat, 11è année, (Nov. 1958), p. 37 sq. Trad. franç. S. Muller. Notes sur la Littérature. p. 171 à 199 . Paris : éd. Flammarion, 1984. 441 p.

\section{NOTAS}

${ }^{1}$ LUKÀCS, Gyorgy. La Théorie sur le Roman. Trad. J. Clairevoye. (Coll. Médiations, n. 4). Paris : Ed. DenoëlGonthier.

${ }^{2}$ LUKÀCS, Gyorgy. L'Ame et les Forme. Trad. G. Haarscher. (Coll. Bibliothèque de Philosophie). Paris: Ed. Gallimard, 1974.

${ }^{3}$ LUKÁCS, Gyorgy. Histoire et conscience de classe. Trad. K. Axelos et J. (Coll. Arguments). Bois. Paris : Ed. de Minuit, 1960.

${ }^{4}$ GABEL, J. La Fausse conscience. (Coll. Arguments). Paris : Ed. de Minuit,1962. 